\title{
Analysis of the Application of National Standards of Education in Elementary Schools
}

\author{
Osa Juarsa ${ }^{1, *}$, Rambat Nur Sasongko ${ }^{1}$ and Novian Mashuri ${ }^{2}$ \\ ${ }^{1}$ Lecturer in Study Program of Educational Administration Master, Faculty of Education, Bengkulu University \\ ${ }^{2}$ Students in Study Program of Educational Administration Master, Faculty of Education, Bengkulu University \\ "Corresponding author. Email: juarsaosa@yahoo.com
}

\begin{abstract}
Elementary School (ES) is held based on the National Education Standard (NES). This national standard is a reference for every school. The problem is that there are schools that have not implemented these national standards thoroughly. It also includes elementary school levels that have not implemented it. This study aims to analyze the application of national education standards in elementary schools, seen from the real conditions, problems and challenges ahead. This study uses a policy evaluation method. This research was conducted at the elementary school level in North Bengkulu Regency, Bengkulu Province, Indonesia. Data collection techniques with checklists, interviews, observation, and documentation study. Data were analyzed quantitatively and qualitatively. The results showed that the application of national education standards in primary schools has not been effective; schools have almost reached the target of national education standards. There are schools that implement with high levels of achievement (fully implementing) and vice versa there are schools with low levels of implementation (less fully). Public schools and private schools have achieved NES implementation in the same category, namely almost effectively and almost reaching the status of "national standard school". There are a number of problems, including lack of community awareness and contribution, inadequate conditions of facilities and infrastructure, limited funds, lack of concern and contribution from the government. Suggestions are provided to local and central government leaders, heads of education offices, and school principals, to programmatically fulfilling NES in ES in a concrete and operational manner.
\end{abstract}

Keywords: National education standards (NES), Elementary school (ES), Public and private school.

\section{INTRODUCTION}

A quality school is a school that is organized with reference to national education standards. Indonesia already has a national policy in the form of national education standards. This national standard has been stipulated by Government Regulation (GR) No. 19 of 2005 on National Education Standards (NES). Government Regulation (GR) No. 19 of 2007 concerning National Education Standards (NES) regulates the standards of content, process, competence of graduates, management, educators and education personnel, facilities and infrastructure, financing, and education assessment. The eight standards have been operationalized into ministerial regulations in more detail and detail according to school levels [1].

National education standards are basically the minimum criteria for the education system in all regions of Indonesia. These national standards are aimed at guaranteeing and controlling the quality of education in order to educate the nation's life and to shape the character and civilization of the nation with dignity. The function of this standard is as a basis for planning, implementing and supervising education in order to realize quality national education [2].

This national standard is the main guideline for school administration [3]. Each school in managing education must be guided by the national education standards. Likewise, the school's final assessment, such as school accreditation, refers to the implementation of national education standards. In America, national education standards do not come and are set by the government [4]. However, it emerged from various national bodies, such as the National Council of the Teachers of Mathematics (NCTM) which published mathematics teaching standards in 1989. The publication of these standards subsequently inspired the formation of national education standards. This condition illustrates that the national education standards in Indonesia appear to be based on "top down". The central government is more dominant in regulating education delivery [5].

Several research results indicate that the application of national standards has positive and negative aspects. For example, Sasongko's research (2015) [6]; Sasongko (2018) [7]; and Rusdiana and Nasihudin (2018) [8] show that the national standard of 
education has advantages, including: (a) the implementation of schools in all regions of Indonesia is the same reference, (b) the quality of education at various levels of school is guaranteed, (c) the community becomes confident in send their children to school, because the standards are the same, (d) the quality of education is evenly distributed throughout Indonesia, and (e) can increase the enthusiasm of schools to be more standardized nationally. The weaknesses include: (a) the territory of Indonesia is very large and the number of education units requires a lot of money in order to become a national standard, (b) the system of education in Indonesia refers to decentralization, so that the local governments' concern is very varied. the application of national education standards, (c) corrupt practices as a disease of unscrupulous state officials resulting in the implementation of national education standards, (d) the regional budget affects the level of application of national education standards, and (e) the availability and quality of human resources in a region greatly affects the application of national education standards. National education standards have been refined again through Government Regulation no. 32 of 2013 concerning revision of national education standards. This revision is proof of commitment from the government so that the delivery of this education can be in accordance with the provisions of the applicable laws. Schools as one of the formal institutions that have the task of providing education must also be guided by national education standards, at various levels of school.

National education standards are the minimum criteria regarding various relevant aspects in the implementation of the national education system and must be met by educational providers and / or education units in all jurisdictions of the Republic of Indonesia (GR No. 19 of 2005 and GR No. 32 of 2013). The function of this national standard is as a basis for planning, implementing and supervising education in the context of realizing quality national education. The aim of the national education standards is to guarantee the quality of national education in order to educate the nation's life and shape the character and civilization of the nation with dignity [9].

The national education standards set by the government consist of eight standards, namely content standards, process standards, graduate competency standards, teacher and education staff standards, facilities and infrastructure standards, management standards, financing standards and educational assessment standards. These eight standards are one unit that must be applied by education units to ensure the quality of education management [2]. Quality education management can have a positive impact on quality graduates [10] [11].

Quality education is in accordance with established national standards [4] [3]. Burton illustrates in America that the states are almost entirely compliant with the standards set by the government. This provides benefits for the community not to hesitate for the education of their children and the implementation of education in each educational unit is in accordance with government policy [10]. National education standards are an obligation to apply. This is based on rationale that if national standards are not applied in schools, then these schools are certainly not standard. The impact is in the form of low learning achievement, low graduation rates, schools that are less able to compete with other schools, and lack of community image and trust in schools. This condition can cause schools to not get prospective students who register. Thus the school could be closed and not allowed to provide education by the government [12].

The results of a field study in Bengkulu province show that the government has not officially conducted research on the application of national education standards. Likewise, the local education office has not conducted similar research. Research on the application of national standards in elementary schools (ES) is very important as a basis for improving and improving the quality of education starting from the basics. This research is very necessary, so that theoretically and practically it is useful for the benefit of improving ES performance. Apart from this, the real problems related to the implementation of national standards in elementary schools that have not been resolved can be resolved appropriately and accurately.

This research departs from the problem that in elementary schools the application of national education standards is not yet in accordance with the provisions. This research problem can be formulated as follows: "Is the application of national education standards in elementary schools in accordance with the established national standards?" This problem can be described into two sub-problems, namely: (1) How is the description of the implementation of national education standards in elementary schools? And (2) What are the real problems faced by elementary schools in implementing national education standards in order to improve school quality?

The purpose of this study was to analyze the application of national education standards in elementary schools. Its specific objectives are to: (1) 
evaluate the application of national education standards at the elementary school level, and (3) describe the real problems faced by elementary schools in implementing national standards in order to improve school quality.

It is hoped that this research can be used as input for the improvement and enhancement of policies for implementing national education standards in elementary schools, local education offices, improving primary school performance, improving the roles of school principals, teachers and support staff, and improving the design of school quality

\section{RESEARCH METHOD}

This study uses a policy evaluation method with a descriptive approach [13]. This study aims to analyze the application of national education standards in elementary schools. The evaluation study approach uses a countenance model, namely with a detailed evaluative description of the application of national education standards at the primary school level and real problems in the field.

This research was conducted at elementary schools in Bengkulu province. The study population was the principal of public elementary schools in Bengkulu Utara district, amounting to 254 people or schools, consisting of 230 public elementary schools and 24 private elementary schools. The selection of research samples was chosen with a purpose by considering the representation of the school, location, and the type of data collected [13]. The total sample was 130 school principals, consisting of 115 from public schools and 15 from private schools.

The data collection technique was carried out by means of a checklist questionnaire and short entries about the problems faced. A checklist questionnaire was used to analyze the implementation of national education standards in schools. This questionnaire contains the achievement of the implementation of national standards of education in schools, which is illustrated by a percentage. The questions asked about the achievement of the implementation of 8 standards, namely the passing standards, content, process, teachers and education personnel, facilities and infrastructure, financing, management, and assessment. Apart from this, it was also asked about the problems faced in implementing these national standards.

Data were analyzed using evaluative techniques, namely by analyzing the implementation of national education standards in schools. The implementation of national education standards is said to be effective, if it is in accordance with the national education standard policies set by the government [14] [15]. Evaluative analysis using descriptive statistical techniques (percent and mean). This is because the type of data is in the form of quantitative data (achievement of the percentage of national education standards and the mean) [13].

\section{RESULTS AND DISCUSSION}

\subsection{Research Result \\ 3.1.1. Implementation of National Education Standards in Primary Schools}

The implementation of NES in elementary schools is something that must be done. That is because besides being a national policy, it can also improve the quality of education in schools. Standards or criteria for the effectiveness of the NES application which are used as a reference for analysis are as follows.

Table 1. Criteria for the Effectiveness of NES Implementation in Schools

\begin{tabular}{|l|l|l|l|}
\hline $\begin{array}{c}\text { NES percent } \\
\text { achievement }\end{array}$ & \multicolumn{1}{|c|}{$\begin{array}{c}\text { Effectiveness } \\
\text { status }\end{array}$} & School categories & \multicolumn{1}{|c|}{ Follow up } \\
\hline $90-100 \%$ & effective & $\begin{array}{l}\text { National Standard } \\
\text { School }\end{array}$ & $\begin{array}{l}\text { Need to be maintained and strived to } \\
\text { reach 100\% }\end{array}$ \\
\hline $80-89 \%$ & almost effective & Almost standard & Need to make efforts to be higher \\
\hline $70-79 \%$ & Less effective & Less standard & $\begin{array}{l}\text { It needs to be fulfilled in order to } \\
\text { reach high }\end{array}$ \\
\hline $60-69 \%$ & not yet effective & Not yet standard & Need to be filled with hard work \\
\hline below 59\% & not very effective & Not at all standard & $\begin{array}{l}\text { Need to be fulfilled on the whole } \\
\text { with hard work }\end{array}$ \\
\hline
\end{tabular}

The results showed that the achievement of the implementation of national education standards in elementary schools was not sufficient to fulfill all the NES demands. The average fulfillment of national 
standards is $83.62 \%$. If you look at the standard criteria for implementing NES, then the achievement is in the category of almost effective and includes almost standard schools. The detailed results can be seen in the following table.

Table 2. Results of Achievement of NES Implementation in ES (in percent)

\begin{tabular}{|c|c|c|c|c|c|c|c|}
\hline \multirow{2}{*}{ No } & \multirow{2}{*}{$\begin{array}{l}\text { National Education Standards } \\
\text { Components }\end{array}$} & \multicolumn{2}{|c|}{ State school } & \multicolumn{2}{|c|}{ Private school } & \multicolumn{2}{|c|}{ Average } \\
\hline & & $\mathbf{n}$ & $\%$ & $\mathbf{n}$ & $\%$ & $\mathbf{n}$ & $\%$ \\
\hline 1 & Passing standards & 115 & 98.0 & 15 & 96.0 & 130 & 97.0 \\
\hline 2 & Standard content & 115 & 76.0 & 15 & 72.0 & 130 & 74.0 \\
\hline 3 & Process standard & 115 & 84.0 & 15 & 88.0 & 130 & 86.0 \\
\hline 4 & $\begin{array}{l}\text { Teacher and education staff } \\
\text { standards }\end{array}$ & 115 & 86.0 & 15 & 78.0 & 130 & 82.0 \\
\hline 5 & $\begin{array}{lll}\text { Standard facilities } & \text { and } \\
\text { infrastructure } & & \end{array}$ & 115 & 76.0 & 15 & 72.0 & 130 & 74.0 \\
\hline 6 & Financing standards & 115 & 88.0 & 15 & 82.0 & 130 & 85.0 \\
\hline 7 & Management standards & 115 & 92.0 & 15 & 90.0 & 130 & 91.0 \\
\hline 8 & Assessment standard & 115 & 84.0 & 15 & 76.0 & 130 & 80.0 \\
\hline & Average & 115 & 85.50 & 15 & 81.75 & 130 & 83.62 \\
\hline
\end{tabular}

By reading table 2 above, it can be explained that the achievement of NES in Public ES is better than in private ES. The average achievement at Public ES is $85.50 \%$, while in private ES it is $81.75 \%$. The two types of schools have the same status, that is, they are in the category of almost effective or almost standard schools. This condition means that schools have not been able to meet national education standards. Primary schools still have to make efforts to improve which aspects of the NES components need to be improved.

If viewed from the NES component, the highest achievement of NES application was the passing standard component (97\%) and management standard $(91 \%)$. The NES components with low achievement were content standards (school curriculum) (74\%) and facilities and infrastructure standards (74). Both NES components are categorized as less effective or less standard. The process standards (86\%), teacher and education staff standards (82\%), financing standards $(85 \%)$, and assessment standards $(80 \%)$, were included in the category of nearly effective or almost standard.

\subsubsection{Real Problems in Implementing NES in Elementary Schools}

ES in implementing NES experiences a number of real problems. This can be seen from the achievement of the NES percentage. Almost no school has reached the target of one hundred percent and is categorized as the national standard school. Elementary school principals generally convey a number of problems faced, why schools have not been able to fulfill NES in full. There are several real problems in schools in implementing NES, described in the following table 3 .

Table 3. Real Problems in the Implementation of NES in ES

\begin{tabular}{|c|l|c|c|c|c|c|c|}
\hline \multirow{2}{*}{ No } & \multicolumn{1}{|c|}{ Kinds of problems } & \multicolumn{2}{|c|}{ State schools } & \multicolumn{2}{c|}{ Private schools } & \multicolumn{2}{c|}{ Total } \\
\cline { 3 - 8 } & \multicolumn{1}{|c|}{$\mathbf{f}$} & $\mathbf{\%}$ & $\mathbf{f}$ & $\mathbf{\%}$ & $\mathbf{f}$ & $\mathbf{\%}$ \\
\hline 1 & $\begin{array}{l}\text { Concern and contribution from the } \\
\text { principal is lacking }\end{array}$ & 8 & 6.15 & 0 & 0 & 8 & 6.15 \\
\hline 2 & $\begin{array}{l}\text { Less concern and contribution from } \\
\text { teachers }\end{array}$ & 26 & 20.00 & 4 & 3.07 & 30 & 23.07 \\
\hline 3 & $\begin{array}{l}\text { Less concern and contribution from staf } \\
\text { education }\end{array}$ & 32 & 24.61 & 8 & 6.15 & 40 & 30.76 \\
\hline 4 & $\begin{array}{l}\text { Less concern and contribution from } \\
\text { school committee }\end{array}$ & 98 & 75.38 & 15 & 11,54 & 113 & 86.92 \\
\hline 5 & Less concern and contribution from head & 101 & 77.69 & 15 & 11.54 & 116 & 89.23 \\
\hline
\end{tabular}




\begin{tabular}{|c|l|c|c|c|c|c|c|}
\hline & of the education office & & & & & & 82.31 \\
\hline 6 & $\begin{array}{l}\text { Less concern and contribution from local } \\
\text { government }\end{array}$ & 92 & 70.77 & 15 & 11.54 & 107 & 97.69 \\
\hline 7 & $\begin{array}{l}\text { Less concern and contribution from } \\
\text { central government }\end{array}$ & 112 & 86.15 & 15 & 11.54 & 127 & 100.0 \\
\hline 8 & $\begin{array}{l}\text { Less concern and contribution from } \\
\text { general community }\end{array}$ & 115 & 88.46 & 15 & 11.54 & 130 & 41.54 \\
\hline 9 & $\begin{array}{l}\text { Lack of guidance and supervision of the } \\
\text { implementation of NES in schools }\end{array}$ & 42 & 32.31 & 12 & 9.23 & 54 & 100.0 \\
\hline 10 & $\begin{array}{l}\text { The condition of school facilities and } \\
\text { infrastructure is lacking }\end{array}$ & 115 & 88.46 & 15 & 11.54 & 130 & 100.0 \\
\hline 11 & Insufficient school financial conditions & 115 & 88.46 & 15 & 11.54 & 130 & 36.92 \\
\hline 12 & $\begin{array}{l}\text { Others (lack of continuous evaluation, } \\
\text { lack of coordination / meeting of leaders, } \\
\text { less focus on meeting NES) }\end{array}$ & 42 & 32.31 & 6 & 4.61 & 48 & \\
\hline
\end{tabular}

Based on the data in the table above, it can be interpreted that it turns out that all public and private elementary schools have a number of problems in implementing NES. The main problems (of which there are many frequencies) include: (1) lack of awareness and contribution from the surrounding community in helping to meet the application of NES $(100 \%)$, (2) the condition of facilities and infrastructure that are lacking in each school (100\%), (3) the school's financial condition is inadequate for school needs to meet the achievement of NES (100\%), (4) lack of concern and contribution from the central government in overcoming NES fulfillment in schools (97.69\%), lack of concern and contribution from the head of the education office in overcoming NES fulfillment in schools $(89.23 \%)$, (5) lack of concern and contribution from the school committee in overcoming NES fulfillment in schools $(86.92 \%)$, (6) lack of concern and contribution from local governments in overcoming NES fulfillment in schools (82.31\%).

Other problems faced by schools are less frequent (below 50\%), such as: (1) lack of guidance and supervision of schools in implementing NES (41.54\%), (2) other problems (lack of continuous evaluation, coordination / lack of leadership meetings, lack of focus on meeting NESs (36.92\%), (3) lack of concern and contribution of education personnel in overcoming NES compliance in schools $(30.76 \%)$, (4) lack of concern and contribution from teachers in overcoming NES fulfillment in schools (23.07\%), and (5) lack of concern and contribution from school principals in overcoming NES fulfillment in schools $(6.15 \%)$.

\subsection{Discussion}

The application of national education standards in primary schools, both public and private, is not yet in accordance with government policy standards. The average fulfillment of national standards is $83.62 \%$, including in the almost effective category and including almost standard schools. Thus, the implementation of NES in ES is not in accordance with government policy. The standard from the government, namely the application of NES in each school is completely met or one hundred percent. If each school can meet fully and thoroughly the eight national standards, then it can be called the National Standard School (SSN) [5].

It is interesting to study where the results of the implementation of NES in Public ESs are better than in Private ESs, occupying the same category position which is almost standard. Both of them achieved NES for Public ES on an average of $85.50 \%$, while in private ES, the average was $81.75 \%$. The two types of schools have the same status, that is, they are in the category of almost effective or almost standard schools. Both have not been able to achieve the national education standard. In this condition, the two types of schools must continue to strive in order to be able to improve the full implementation of NES in all components [16] [17].

The results of Sasongko, Somantri, and Wachidi's [2] research on the implementation of NES at various school levels illustrate that public and private schools tend to have different results. Public schools have a higher level compared to private schools in implementing NES in schools. However, this research has the same category and NES application status. Likewise for the NES component, each component has different results [2] [18]. This research also shows the same results, such as high and low achievement of NES implementation. The NES component with the highest achievement was the component of graduation standards (97\%) and management standards (91\%). The 
NES components with low achievement were content standards (school curriculum) $(74 \%)$ and facilities and infrastructure standards (74). In process standards $(86 \%)$, teacher and education staff standards (82\%), financing standards (85\%), and assessment standards $(80 \%)$, are medium standards and fall into the category of nearly effective or nearly standard.

Other studies that examine the application of NES in schools, such as Triwiyanto [19]; Sasongko [6]; Sasongko [7]; Sasongko and Sahono [9]; Rusdiana and Nasihun [8]; Sasongko [3]; and Barton [4] provide research results that the achievement of the application of national standards has not been able to achieve full standard compliance. Every school has a number of problems and tough work to fulfill this national policy.

In the research, Sasongko and Sahono [9] examined more broadly and gave research results that the application of national education standards has a strong relationship with high school accreditation scores, high exam scores, good community image, and high school achievement. This study did not examine such details. This research does not examine the achievement of implementing NES with other aspects such as the quality of learning outcomes, school performance, school accreditation scores, community image, school achievement, and so on. This study focuses on research activities to evaluate the implementation of NES policies at the elementary school level.

The achievements of implementing NES in each school have different characteristics from one school to another [12]. Characteristics of school principals, teachers, and education staff sufficiently contribute to the results of research [2]. Therefore, schools also have a number of problems in the application of NES. The results of this research illustrate that at the elementary school level, there are a number of problems in implementing NES. The problems that are urgent to be addressed include: (1) lack of concern and contribution from the surrounding community in helping to fulfill the NES implementation, (2) the condition of facilities and infrastructure that are inadequate for each school, (3) the condition of school finances that is inadequate for school needs in order to meet the NES achievement, (4) lack of concern and contribution from the central government in overcoming NES compliance in schools, lack of concern and contribution from the head of the education office in overcoming NES fulfillment in schools, (5) lack of concern and contribution from the school committee in overcoming compliance NES in schools, and (6) lack of awareness and contribution from local governments in overcoming NES fulfillment in schools. This problem seems to need to be prioritized to be immediately resolved through various means.

The national policy to implement School Based Management (SBM) as the best solution in managing quality schools has not been able to provide optimal results for every school [4]. Each school has its own problems in management to improve school quality. School-based management that has been implemented in schools is actually the basis for quality that is given authority to schools [1]. The implementation of schoolbased management and national education standards each have unique problems. Examples of local government policies, especially the city / district education offices, are not yet fully serious in meeting the national standard for fulfilling the education budget of at least $20 \%$ of the regional budget. The application of school-based management that has not been fully recognized as effective in addressing the problems of implementing education in schools has a number of problems [4] [5] [3]. There are a number of problems that arise when school-based management is implemented in schools, such as schools. school-based management is not yet understood, the education office does not care, the school is running from the road, school staff performs routine work, and lacks serious control or guidance from the authorities.

Similar to the results of Sasongko and Sahono's [9] research on accelerating the fulfillment of NESs, it also shows that many factors affect the achievement of national standards at various levels of school, such as school principals and staff who do not understand how to meet standards in a better direction, financial problems that support fulfillment. national standards, and insufficient facilities and infrastructure adequacy issues. In this condition, there should be concern from the local education office to take concrete steps to overcome problems in implementing NESs that have not reached national standards.

\section{CONCLUSION}

The conclusion of this research shows that the application of NES in ES has not been implemented effectively. This means that the government policy regarding the obligation to implement NES has not been implemented by schools with appropriate results. Achievements leading to national standard schools are almost achieved, leaving little. Between public and private schools, there is no significant difference in the achievement of implementation results.

Primary schools have a number of problems in implementing the NES, such as a lack of concern and 
contribution from the surrounding community in helping to fulfill the NES implementation, lack of adequate facilities and infrastructure, inadequate school financial conditions, lack of concern and contribution from central and local governments, and school committees in overcoming NES compliance in schools. Suggestions to school principals, heads of education offices, regional and central government leaders who are in power should be able to help overcome NES fulfillment in a more concrete and operational manner. Each school should be assisted with technical assistance, provide adequate facilities and infrastructure, as well as adequate finance, so that it can be used to fulfill the NES in full.

\section{REFERENCES}

[1] BNES (Badan Standar Nasional Pendidikan). 2007. Standar Nasional Pendidikan (Buku 1, 2, 3, 4, 5, 6, 7, 8). Jakarta

[2] Sasongko, R.N., Somantri, M., and Wachidi. 2018. The New Challenges of Implementation of School Principals Standards in the Era of Asean Economic Communities (AEC). International Journal of Recent Scientific Research. 9 (9A), Sept 2018, pp. 28733-28736. http://www.recentscientific.com /sites/default/files/11762-A- 2018.pdf

[3] Sasongko, R.N. 2019. Determinants of National Education Standards Application Levels at Various School Levels. Manajer Pendidikan: Jurnal Ilmiah Manajemen Pendidikan Pascasarjana, 13 (1), April 2019, pp. 63-72. http://ejournal.unib.ac.id/i ndex.php/manajerpendidikan

[4] Barton, P. 2009. National Education Standards: Getting Beneath the Surface. New Jersey: Policy Information Center. https://www.ets.org/Media/Research/pdf/PICNAT EDSTAND.pdf

[5] ACDP. 2013. Evaluation of International Standard Schools in Indonesia. Jakarta: Ministri of Education and Culture

[6] Sasongko, R.N. 2015. Strategies to Overcome Poor Madrasahs through the Development of Collaborative-Based Management Models (Educational Action Research at Different Levels of Madrasahs in Bengkulu Province). Madania: Jurnal Kajian Keislaman. 19 (2), 185-194
[7] Sasongko, R.N. 2018. The Implementation of National Standards of Education for School Quality Improvement Facing the 21st Century (Descriptive Evaluative Studies in Various Levels of Schools in Bengkulu Province of Indonesia). International Journal of Current Research in Life Sciences. 07 (08), August 2018, pp 2647-2651. http://www.ijcrls.com/sites/defa ult/files/issuespdf/01660..pdf

[8] Rusdiana, A. and Nasihudin.N. 2018. The Implementation of National Standard-Based Curriculum in Private Islamic Higher Education: Leadership Impact. Jurnal Pendidikan Islam 4 (1) (2018) 87-98

[9] Sasongko, R.N. dan Sahono, B. 2018. Accelerating the Fulfillment of NES through the Development of a Performance Audit-Based School Development Model. Bengkulu: Laporan Hasil Penelitian pada LPPM UNIB

[10] Sasongko, R.N. dan Sahono, B. 2016. School Management Innovation Design. Jakarta: Shany Publisher

[11] Septarina, L. and Sasongko, R.N. 2019. Quality Management: Impact of Leadership Mobilization on Institutional Quality. International Journal of Research Science \& Management, 6 (5), pp. 1-8. http://www.ijrsm.com/issues\%20pdf\%20file/Arch ive-2019/May-2019/1.pdf

[12] Bandur, A. 2009. The Implementation of School Based Management in Indonesia: Creating Conflict in Regional Level. Journal of NTT Studies, Vol. 1, No. 1, 16-27

[13] Burn, R. B. 2009. Introduction to Research Methods. Sidney: Longman

[14] Government Regulation No. 19 of 2005 of National Education Standard

[15] Government Regutaion No. 32 of 2013 of Change of GR of No. 19 of 2005 of National Education Standard

[16] Bosshardt, W. and Walstad, W. 2014. National Standards for Financial Literacy: Rationale and Content, The Journal of Economic Education, Vol. 45, 2014, http://www.tandfonline.com/toc/vece20/curent

[17] Burke, L. and Marshall, J.A. 2010. Why National Standars Wont Fix American Education: 
Misaligment of Power and Incentives. https://www.heritage.org/research/report/2010/05

[18] Sasongko, R.N. and Fetrianggi, R. 2020. An Analysis of the Management of Poor Student Assistance to Improving Learning Achievement. International Journal of Research Science \& Management, 7 (6), pp. 32-38. http://www.ijrsm.com/issues\%20pdf\%20file/Arch ive-2020/June-2020/6.pdf
[19] Triwiyanto.T. 2013. Standar Nasional Pendidikan Sebagai Indikator Mutu Layanan Manajemen Pendidikan. Jurnal Ilmu Pendidikan. Vol. 19. No. 2. http://journal.um.ac.id/index.php/jip/article/view/4 208 